\title{
Agricultural Training and Its Impact on Food Crop Production in Cameroon
}

\author{
Mbu Daniel Tambi ${ }^{{ }^{*}}$ \\ ${ }^{1}$ Department of Economics, University of Bamenda - Cameroon \\ (Received October 23, 2018; Accepted March 7, 2019; Published March 26, 2019)
}

\begin{abstract}
Agricultural training has an important position in agriculture development, food security and poverty alleviation in Cameroon. The objectives of this study are to examine the impact of agricultural training on food crop production; determine the factors influencing agricultural training, decompose the effect of agricultural training type on food crop production, and recommend relevant economic policies on the basis of our analysis. Using data from the 2007 MINADER and data from the 2007 Household Consumption Survey, we used the control function model to estimate our result from STATA 13.0. We observed that the 2SLS, Control Function without interaction and Control Function with interaction results revealed that household agricultural training strongly correlates with food crop production. Also professional, workshop and on the farm training strongly affects agricultural production, with probability points of 2.6, 0.3 and 2.8 percent of increasing agricultural production respectively. Farm training becomes a high priority for increasing agricultural production. There are considerable opportunities to take advantage of agricultural training in terms of increase in cereal productivity. The decision makers, civil society organizations and stakeholders operating in agriculture should multiply agricultural training in both former and informer training, through the creation of agricultural schools, workshop/seminars and on the field training.
\end{abstract}

Keywords: farmer, agricultural training, household, food crop production, Cameroon

JEL Classification: I25, D13, Q12

\section{INTRODUCTION}

Food crop production in Cameroon was dominated by small scale farmers' food crop producers (Tanjong, 2008). Majority of farming operations are carried out by using trading cropping systems and traditional crop varieties. In all these, knowledge on what to plant and where to plant for maximum productivity and cooperation by the community is very important.

Cereal crops are equally most derivate products in the agricultural family in Cameroon. Cereal crops such as maize, rice, sorghum are widely consumed by almost all households in Cameroon and most African countries. They are equally the most derivate products, for example, maize can be

\footnotetext{
* Corresponding author email: tambi2015@yahoo.co.uk, ISSN 2615-6075 online; ISSN 2615-6946 print @UWG Press, 2019

OJS http://publishing-widyagama.ac.id/ejournalv2/index.php/jsed/
}

derivate as well as consumed in many other forms, such as corn fufu, pap, corn beer, Koki, dried or roasted maize. It can also be consumed alongside many other foods such as beans, vegetables, etc. Maize is produced in large quantities in all the ten regions of Cameroon. Among the six important food crops, maize is widely grown crops and the most affordable in terms of market price and cost of seeds and widely grown crop in Africa and Cameroon (Epule \& Bryant, 2015).

The place of agricultural training in determining agricultural production in Cameroon is indisputable in this era of population growth. Training in agriculture will determine the way farmers manage their agricultural farms and hence the quantity of produce a farmer will receive. Agricultural training goes beyond the use of farm tools such as hoes, cutlass, diggers, wheel-barrows and or tractors, to cultivate farms or raise animals for local consumption or commercial purposes. Training nowadays includes the transformation of 
agricultural products into many other forms, to create variety, make more money and feed the masses of the fast-growing world population. This means that agricultural training is an important element of food security and poverty alleviation in Cameroon.

Education is a factor which has an impact on agricultural productivity. Närman (1994) noted that education significantly has an impact on agricultural productivity. Farmers with years of basic schooling are more likely to adopt and properly apply agricultural innovations. Training held by various agricultural service institutions would be efficient if applicants possess an appropriate background in formal education. Agricultural education produces both cognitive outputs of schooling (the transmission of specific information and the formation of general skills and proficiencies) and non-cognitive changes (attitudes, beliefs, and habits)

Literacy and numeracy enhance farmers behave rightly to acquire and understand information and to calculate appropriate input quantities into farms. Equally, it leads farmers to a greater willingness to accept a risk, adopt innovations, save for investment and generally to embrace productive practices (Appleton \& Balihuta, 1996) (Cotlear, 1990). Further, Rosenzweig (1995) reveals that schooling enables farmers to learn on the job more efficiently. Also, it was reported that some success stories confirm prior findings to using non-formal education and focusing on learning-discovery approach and filling in the gaps in farmer's knowledge misconceptions (Sligo \& Massey, 2007).

Närman (1994) affirms the assumption that farmers without education can withstand innovation and technical evolution in agriculture, meaning that if the entire farming community is to be concerned by a process of change. It implies that the extension personnel must pay special attention to non-educated farmers. While Lovell (1993) assume that education instead affects the efficiency of the farmer in transforming inputs into output but do not affect the process by which production occurs. In all these the conclusion is that agricultural training is a strong determinant of agricultural production and sustainability in the world at large.
Närman (1994) intimated that there is a robust relationship between post-secondary education and technological development. Skilled agricultural manpower is needed for research and for the extension of innovations and consequently agricultural production. It can be said that the basic requirement for mass agricultural production is an effective educational structure that includes both general schooling and more specialized vocational training. A study by Tripp, Wijeratne, \& Piyadasa (2005) confirms that training is important in the enhancement of farmers 'skills in agricultural works while studies on the effectiveness of training for farmers showed that only training programs that carefully revised and designed to address particular farm needs can increase productivity in farms.

Table 1. Distribution of Household Participation in Agricultural Training

\begin{tabular}{lcrrr}
\hline \multirow{2}{*}{ Region } & \multicolumn{4}{c}{ Type of Agricultural Training } \\
\cline { 2 - 5 } & $\begin{array}{c}\text { Profes- } \\
\text { sional } \\
\text { School }\end{array}$ & $\begin{array}{c}\text { Work- } \\
\text { shop/ } \\
\text { Seminar }\end{array}$ & $\begin{array}{c}\text { The farm } \\
\text { training }\end{array}$ & $\begin{array}{c}\text { No } \\
\text { Training }\end{array}$ \\
\hline Adamawa & 1.0 & 6.5 & 4.3 & 88.3 \\
Centre & 3.3 & 18.3 & 22.4 & 56.0 \\
East & 0.8 & 12 & 11.1 & 76.0 \\
Far North & 0.8 & 4.2 & 1.7 & 93.3 \\
Littoral & 2.1 & 14.3 & 28.9 & 54.8 \\
North & 1.5 & 1.8 & 26.7 & 70.0 \\
North West & 3.4 & 16.3 & 4.8 & 75.6 \\
West & 1.2 & 7.7 & 24.6 & 66.4 \\
South & 3.7 & 8 & 14.8 & 73.4 \\
South West & 1.9 & 24.3 & 11.3 & 62.5 \\
Total & $\mathbf{1 . 6}$ & $\mathbf{8 . 7}$ & $\mathbf{1 1 . 8}$ & $\mathbf{7 7 . 9}$ \\
\hline
\end{tabular}

Source: MINADER (2013)

Ashby et al. (2008) noted that the demand for agricultural commodities is changing and new opportunities are challenging farmers, for instance, increase demand for higher value products, the introduction of advanced agricultural technology as well as the new variety of seeds. In order to increase incomes and improve livelihoods, the farmer needs to have a good mastery of the market situation and system of production (Noor \& Dola, 2011). Given the case of Bangladeshi small farmers, Murshed-E-Jahan \& Pemsl (2011) stated that the capacity building of farmers who engage actively in training is more valuable than the provision of financial support in terms of raising production and income. 
Agricultural training in Cameroon may either take the form of professional training, workshop or seminar, on the farm training and or no training. Table 1 shows that in Cameroon, 77.9 percent of agricultural households had no training. It means that agricultural training is still a critical issue to be discovered and understood in Cameroon. The table reveals that considering the national territory, only 1.6 percent of farmers received professional training; 8.7 percent had workshop/seminar training while 11.8 percent of household farmers received on the farm training.

The reasons for low agricultural training can be explained below:

a) Culturally, most rural dwellers in Cameroon believe that one doesn't need to be trained to do agriculture. This idea in mind becomes difficult to acquire training to a farmer.

b) Lack of knowledge and ignorance has caused many agricultural workers to be indifferent so far as agricultural training is a concern.

c) The government has not yet taken it as a priority to an emphasis on the training of agricultural workers. It's a profession that requires just manpower; it's difficult to find people sacrificing to learn except the government impose on them.

d) Aid from support institutions like international bodies (FAO, WFP, World Bank) to Cameroon agriculture is oriented towards cash and kind (agricultural tools, i.e. hoes, machetes etc).

e) Elites from local communities have also failed to explain the necessity of this exercise to their local environment.

f) Many farmers are still resistant to the adoption of new technology or practices in their methods. This resistant has hindered agricultural training and education.

Agricultural training is therefore important in poverty alleviation, food security and consequently economic growth, however in Cameroon emphasis in increasing agricultural productivity by 2035 is more on improved seeds, increasing the quantity of seeds planted, increase in arable land and increase in farm use equipments as well as creation of available markets for the sales of agricultural products. The government has not yet considered agricultural training to be a priority and there was a practically countable number of institutions and faculty conducting training in agriculture. Most NGOs in this domain have caught the spirit of training, yet they are so few and mostly located in the urban centers meaning the great number of farmers in the rural community do not benefit in the training.

In terms of the gap in the literature, it has not come across any study that has attempted to quantify the effect of training on agriculture in Cameroon. Tanjong (2008) demonstrated in an analytical way the role of higher education on sustainable growth, however, this study failed in using actual data to demonstrate this empirically. Out of Cameroon, many studies have approached this study (Lovell, 1993) (Noor \& Dola, 2011) (Närman, 1994) with controversy in the result. Most of these studies failed to handle the endogeneity problem that may arise as a result of simultaneously determining factors of education and farm productivity or performance and so most of the results are understated. The previous studies also failed in estimating the type of training farmers actually received before determining their global effects. This study attempts to not only handle the problem of endogeneity but we shall also estimate the impact of the type of training on agricultural production in Cameroon.

The main objective of this study is to explore the effects of farmer's participation in agricultural training and the type of agricultural training on food crop production in Cameroon. The objective is specifically formulated as follow: (i) examine the impact of agricultural training on cereal crop production in Cameroon, (ii) determine the factors influencing agricultural training, (iii) decompose the effect of farmer's participation in agricultural training on cereal crop production by type of agricultural training in term of professional, workshop/seminar, and on the farm training, and (iv) recommend relevant economic policies on the basis of the result of this study.

\section{RESEARCH METHOD}

\section{Modeling Approach}

The household production model of time allocation was revisited by (Gronau, 1977). Gronau's model supposes that agricultural household produce and purchase goods are perfect 
substitutes. So a household expends and obtains utility from leisure and a good such as agricultural food crop, which can be produced at home by households or purchase in the market.

Farmers professional training, seminar/workshop and on the farm training, known as agricultural training $(A T)$ as revealed in the literature are associated with agricultural performance such as cereal crop production $(C P)$ as noted earlier we are interested in maize, rice, beans, and groundnuts production. The hypothetical mechanism linking agricultural training to cereal production may be express in the following production function:

$$
\begin{aligned}
& C P_{i}=w_{1} \pi_{b}+\sum_{i} v_{i} A T_{i}+\varepsilon_{1} \\
& A T_{i}=w_{2} \pi_{A T i}+w_{2} \Omega_{A T i}+\varepsilon_{2 i}
\end{aligned}
$$

This equation (1) is our principal equation presenting the causal relationship between agricultural training and cereal production. The estimation of the parameter $v_{i}$ would show the effect of $A T$ on cereal crop production. From this equation; $w_{1}$ represents a vector of exogenous covariates; as noted earlier $v$ is the parameter of the potentially endogenous explanatory variable in the cereal production function, $\pi_{b}$ is the vector of parameters to be estimated and $\varepsilon_{1}$ is the error term refers to both random effects and unobservable variables.

For the fact that (a) it is going to simultaneously determine the determinants of cereal crop production and agricultural training, there is a possibility that a bias will occur in our estimates, (b) considering that there can be omission in the data to be estimated, perhaps omitting a major determinant factor in a regression may also bias our results, (c) it may also be possible that variable of interest interact positively with the error term. All these possibilities have the potential of engineering endogeneity problem, which most former studies principally have ignored.

From equation 2 therefore, $w_{2}$ is a vector of exogenous affecting agricultural training but have no direct influence on cereal crop production. $\pi_{A T i}$ and $\Omega_{A T i}$ are vectors of parameters of exogenous explanatory variables in the reduced form $A T$ function to be estimated; further, $\mathcal{E}_{2 \mathrm{i}}$ is the error term refers to both the random effects and other relevant but unobservable characteristics or complementary inputs and $i$ is $1,2, \ldots . n$.

In this study, the cluster mean of household ownership of radio and television will be used as our instruments. To take care of potential endogeneity bias and non-linear interactions of unobservable variables, it is computed with the observed regressors as specified in the cereal crop production function by regressors simultaneously, as follow:

$$
C P_{i}=w_{1} \pi+v A T_{I}+\gamma_{1} \hat{\varepsilon}_{2}+\gamma_{2}\left(\hat{\varepsilon}_{2} * A T\right)+u
$$

Equation (3) is known as control function specification, from which $\hat{\mathcal{E}}_{2}$ is a fitted $A T$ residual of agricultural financing, derived from the reduced form linear probability model of agricultural training, $\hat{\mathcal{E}}_{2 * A T}$ is interaction of the fitted $A T$ residual with the actual value of agricultural training; $u$ is a composite error term comprising $\mathcal{E}_{1}$ and the unpredicted part of $\varepsilon_{2}$, under the assumption that and $E(u)=0$ and $\pi, \mathrm{v}, \lambda$, and $x$ are parameters to be estimated. Control function variables will purge the structural estimates of potential simultaneity bias and unobserved heterogeneity. Given the set of instruments for agricultural training is absent from equation (3), we imposed the exclusion restriction on the equation so as to include the instruments. The reason for imposing the instruments is for our equitation/regression to be exactly identified.

The terms $\hat{\mathcal{E}}_{2}$ and $\hat{\mathcal{E}}_{2} * A T$ are the control function variables in which they control for the effects of unobserved factors that would otherwise contaminate the estimates of structural parameters. The reduced form $A T$ residual, $\hat{\mathcal{E}}_{2}$ serves as the control for unobservable variables that correlate with $A F$.

If the unobserved variable is linear in $\hat{\mathcal{E}}_{2}$, then it will only be the constant term that will be affected by the unobservable, meaning the estimates of equation (3) will be consistent even without the inclusion of the interaction term. Considering that the expected value of $\hat{\mathcal{E}}_{2 * A T}$ is zero or is linear and supposing there is no sample selection problem, 
the instrumental variable estimate of equation (3) will be unbiased and consistent. In any case, if the correlation is non-linear, then the control function approach is required and the inclusion of $\dot{\varepsilon}_{2} * A T$ in equation (3) will purge the estimated coefficients of the effects of unobservable variables (Wooldridge, 2002) (Card, 2001)

\section{Data Variable}

Variables such as food crop production and farm size are imported from the Ministry of Agriculture and Rural Development (MINADER) and Household Consumption Survey in 2007. The Household Consumption Survey covered a sample of about 11391 households. The results of these surveys were presented for each of the 12 areas of study constituting the 10 regions. Data was used as the control function model to estimate our result from STATA 13.0.

Variable of food crop production captured by rice, yams, maize, and cocoyam The principal endogenous variable is agricultural training; the instruments for the endogenous variable are cluster mean of household ownership of radio and television. The exogenous demographics are household head education such as primary, secondary and higher education, farm experience, number of workers' in agricultural sector, male household head, household size, banking financial support, non-poor households, farm size and farm input such as seeds and fertilizers geographical location of the household.

\section{RESULT AND DISCUSSION}

\section{Characteristics of Farm Household}

Characteristics of household regarding food crop production and agricultural training presented in Table 2. Most people working in the agricultural sector are primary education leavers, with only 6.68 percent from higher education (Tabel 2). Among the workers in this sector; 73 percent receive on the farm training, 59 percent workshop training and 45 percent professional training.

In relation to education, this means that the government still need to step up the educational level of citizens involve in this sector is in terms of circular, technical or vocational education. It should be noted that this is a general tendency with agriculture in most developing countries. Given data from a 1994 USAID fertilizer marketing survey, Croppenstedt \& Demeke (1997) found that literate farmers are more likely to adopt the better use of fertilizer than those who are illiterate.

Food crop production is an important activity in Cameroon, such as maize, sorghum, rice, yams, Irish, sweet potatoes, cassava, and cocoyam were widely planted in the entire territory. These crops are essential contributors to alleviating the food security problem. In this process, about 75.6 percent of workers involved in crop production are working full time, but with only 7.6 percent using modern agricultural tools. This implies that the prevalence of manual work is still very high considering that farmer's farmland size ranges from 8 to 10 hectare. This may also mean the farmland is still highly being underused, most farmers producing below capacity as confirmed by the low use of agricultural input such as fertilizer.

Other reasons for inadequate farm produced can be the high cost of improving seeds and fertilizer. Couple with the fact that financial institution's credit is low due to perhaps inadequate collateral security. The tendency is that farm produce will be low. The detail of our discussion is summarised in Table 2.

Noah (1988) adapted four stages of agricultural technology adoption vis-à-vis the role of education as originally formulated by (Heyneman, 1983). According to them, stage 1 is the traditional farming, where information is passed from father to son, and where little or no schooling is needed. Stage 2 is considered to be a single input adoption, where basic literacy and numeracy are very useful to farmers for understanding instructions and adjusting quantities of the new input. Stage 3 is the adoption of multiple inputs simultaneously, in this case, more than literacy and numeracy are necessary, where basic science knowledge is helpful and lastly, stage 4 is irrigation based farming. In this stage, the farmer is required to make complex calculations of the effects of changes in crops and weather. This stage needs more education for efficient production, education also helps to determine whether a farmer decides to be an early adopter of innovations and the extent to which the new innovation will be used. 
From this formulation (Noah, 1988) accounted that there are at least three reasons agricultural stages: (1) those with schooling tend to be more affluent and are in less danger of starvation if a prospective innovation is unsuccessful; (2) educated farmers may be more likely to be contacted by agricultural extension workers looking for model farmers to test innovations and (c) literate farmers are better able to acquire information about potential innovations and to make rational evaluations of the risks involved in trying new inputs, crops or methods.

\section{Determinants of Agricultural Training}

Relationship of demographic characteristics of the household and its influence on the agricultural training presented in Table 3 . Training in agriculture is strongly and positively correlating with farmers used of modern technology, male household head, cost of fertilizer, household size, higher education, acquisition of television, banking financial support to farmers and non-poor households (see, column 1 of Table 3 , reduced form equation result).

In the same way, agricultural training is negatively correlating with rainfall variability, number of agricultural workers, cost of seeds, farm size, farm experience, urban residence, farming experience, primary and secondary education. Principally, farmers in possession of modern farming equipment will necessitate training to manage and use the equipment. This explains why the acquisition of modern equipment is strongly correlating with food crop production. Technology varies; hence each agricultural tool has its specific training for a better application in the agricultural farms. The ability to use the equipment will depend on the farmer initial training such as professional, workshop and on the farm training.

Tabel 2. Characteristics of Farm Household

\begin{tabular}{|c|c|c|c|c|}
\hline Variables & Mean & Std. Dev. & Min & Max \\
\hline Cereal Crop Production & 11.248 & 0.590 & 10.565 & 12.600 \\
\hline HH Agricultural Training & 1006 & 413 & 223 & 1510 \\
\hline HH ownership of Radio_MPU & 0.494 & 0.500 & 0 & 1 \\
\hline HH ownership of Television_MPU & 0.307 & 0.461 & 0 & 1 \\
\hline Farmer Use Modern Farm Technology & 0.077 & 0.266 & 0 & 1 \\
\hline Rainfall Variability & 470 & 236 & 216 & 941 \\
\hline Number of Agricultural workers in $\mathrm{HH}$ & 0.756 & 0.733 & 0 & 1 \\
\hline HH Male Sex & 0.744 & 0.437 & 0 & 1 \\
\hline Log of cost of seeds & 1.806 & 1.166 & 0 & 8.294 \\
\hline Log of farm size & 9.682 & 0.602 & 8.825 & 10.592 \\
\hline Log of cost of fertilizer & 2.817 & 1.141 & 0 & 9.510 \\
\hline $\mathrm{HH}$ Size & 4.393 & 3.025 & 1 & 43 \\
\hline Primary Education & 0.336 & 0.472 & 0 & 1 \\
\hline Secondary Education & 0.321 & 0.467 & 0 & 1 \\
\hline Higher Education & 0.067 & 0.250 & 0 & 1 \\
\hline Farming Experience & 42.006 & 15.433 & 0 & 95 \\
\hline Non poor $\mathrm{HH}$ & 0.709 & 0.454 & 0 & 1 \\
\hline Banking Financial Support & 0.175 & 0.380 & 0 & 1 \\
\hline Urban Residence & 0.370 & 0.483 & 0 & 1 \\
\hline Farmer Professional Training & 201.450 & 100.466 & 80 & 370 \\
\hline Farmer Workshop Training & 1106.596 & 701.191 & 180 & 2430 \\
\hline Farmer On the Farm Training & 1710.733 & 958.517 & 170 & 2890 \\
\hline
\end{tabular}

Source: The 2007 Cameroon Consumption Survey; Sample size: 11391

Men have a higher tendency of being trained as compared to women, especially in the urban community. The men, in general, are more involved in cash crop production while the female is more in food crop production to meet the subsistent and nutritional need of the family. However, following the widely distributed presence of nongovernmental organizations involved in all manner of capacity building for the women, they are, therefore, motivated to constitute themselves into Common Initiative Groups, Associations or Cooperatives.

With such groups, women or farmers, in general, can easily be trained. The cost of fertilizer is another factor strongly correlation with food crop production. Fertilizer acquisition constitutes an 
extra cost for agricultural production. Therefore, it becomes necessary for farmers to be trained in using the various types of fertilizer and most importantly their practical farm applications. As to what follows, this enables them to maximize their full benefit in terms of farm yield and hence compensating for the production cost. With regards to household size, it observed that the higher the number of persons in a given household, the more the quest for food. This can only be achieved through mass production, by the acquisition of technical and professional knowledge.

Table 3. Determinant of Agricultural Training

\begin{tabular}{|c|c|c|c|c|}
\hline Variables & Reduced Form & 2SLS & $\begin{array}{l}\text { CF Without } \\
\text { Interaction }\end{array}$ & $\begin{array}{c}\text { CF With } \\
\text { Interaction }\end{array}$ \\
\hline HH Agricultural Training & $\mathrm{n} / \mathrm{a}$ & $0.027 * * *$ & $0.027 * * *$ & $0.029 * * *$ \\
\hline Farmer Use Modern Farm Technology & $22.194 * * *$ & -0.089 & $-0.089 * * *$ & $-0.100 * * *$ \\
\hline Rainfall Variability & $-0.112 * * *$ & $-0.000 * * *$ & $-0.000 * * *$ & $-0.001 * * *$ \\
\hline Number of Agricultural workers in $\mathrm{HH}$ & -13.945 & 0.036 & $0.036 * *$ & $0.042 * * *$ \\
\hline $\mathrm{HH}$ head male Sex & $36.056 *$ & $-0.139 * *$ & $-0.139 * * *$ & $-0.143 * * *$ \\
\hline Log of cost of seeds & $-11.144 *$ & $0.037 * *$ & $0.037 * * *$ & $0.059 * * *$ \\
\hline Log of farm size & $-124.994 * * *$ & $0.770 * * *$ & $0.770 * * *$ & $0.850 * * *$ \\
\hline Log of cost of fertilizer & $29.104 * * *$ & $-0.061 * *$ & $-0.061 * * *$ & $-0.092 * * *$ \\
\hline HH Size & $3.430 *$ & -0.010 & $-0.010 * *$ & $-0.009 * * *$ \\
\hline Primary Education & $-58.504 * * *$ & $0.168 * *$ & $0.168^{* * *}$ & $0.194 * * *$ \\
\hline Secondary Education & $-97.040 * * *$ & $0.169 *$ & $0.169 * * *$ & $0.225 * * *$ \\
\hline Higher Education & $282.520 * * *$ & $0.586 * *$ & $0.586 * * *$ & $0.668 * * *$ \\
\hline Farming Experience & $-2.101 * * *$ & 0.004 & $0.004 * * *$ & $0.004 * * *$ \\
\hline Non poor $\mathrm{HH}$ & 18.658 & $-0.076 *$ & $-0.076 * * *$ & $-0.058 * * *$ \\
\hline Banking Financial Support & $49.049 * *$ & $0.172 * *$ & $0.172 * * *$ & $0.172 * * *$ \\
\hline Urban Residence & -1.759 & $0.146 * * *$ & $0.146 * * *$ & $0.135 * * *$ \\
\hline HH ownership of Radio_MPU & $-16.473 *$ & $\mathrm{n} / \mathrm{a}$ & $\mathrm{n} / \mathrm{a}$ & $\mathrm{n} / \mathrm{a}$ \\
\hline HH ownership of Television_MPU & $51.705 * *$ & $\mathrm{n} / \mathrm{a}$ & $\mathrm{n} / \mathrm{a}$ & $\mathrm{n} / \mathrm{a}$ \\
\hline Predicted Residual & $\mathrm{n} / \mathrm{a}$ & $\mathrm{n} / \mathrm{a}$ & $-0.002 * * *$ & $-0.001 * * *$ \\
\hline Predicted interaction term & $\mathrm{n} / \mathrm{a}$ & $\mathrm{n} / \mathrm{a}$ & $\mathrm{n} / \mathrm{a}$ & $-0.000 * * *$ \\
\hline Constant & $2,347.694 * * *$ & 1.035 & 1.035 & $0.363 * * *$ \\
\hline R-square & 0.1129 & 0.9677 & 0.6717 & 0.7158 \\
\hline F-Stat [df; p-val] & $\begin{array}{c}10.59[17,11,221 \\
0.0000]\end{array}$ & $\begin{array}{c}16.90[16 \\
11,101 ; 0.0000]\end{array}$ & $\begin{array}{c}74.33[17 \\
11,101 ; 0.0000]\end{array}$ & $\begin{array}{c}83.68[18 \\
11,101 ; 0.0000]\end{array}$ \\
\hline $\begin{array}{l}\text { F test of excluded instruments/ Joint F / } \chi^{2} \\
\text { ( } p \text {-value) test for Ho }\end{array}$ & $\mathrm{n} / \mathrm{a}$ & $\begin{array}{l}3.57[2,11,221 \\
0.0085]\end{array}$ & $\mathrm{n} / \mathrm{a}$ & n/a \\
\hline Angrist-Pischke multivariate $\mathrm{F}$ test & $\mathrm{n} / \mathrm{a}$ & $7.190[0.0075]$ & $\mathrm{n} / \mathrm{a}$ & $\mathrm{n} / \mathrm{a}$ \\
\hline $\begin{array}{l}\text { Cragg-Donald F-Stat [10\% maximal IV relative } \\
\text { bias] }\end{array}$ & n/a & $3.568[19.93]$ & $\mathrm{n} / \mathrm{a}$ & $\mathrm{n} / \mathrm{a}$ \\
\hline Sargan statistic: (Chi-sq(2) P-val) & $\mathrm{n} / \mathrm{a}$ & $0.518[0.4716]$ & $\mathrm{n} / \mathrm{a}$ & $\mathrm{n} / \mathrm{a}$ \\
\hline Durbin-Wu-Hausman $\chi^{2}$ test & $\mathrm{n} / \mathrm{a}$ & $19.328[0.0003]$ & $\mathrm{n} / \mathrm{a}$ & $\mathrm{n} / \mathrm{a}$ \\
\hline
\end{tabular}

People in higher education will always solicit more training as a result of the initial awareness of the importance of training in productivity. Hussain \& Byerlee (1994) clarified that agricultural training increase farm productivity in two ways: (1) general skills acquired in school reduce technical and allocative inefficiencies in production; and (2) attitudes acquired in school encourage the adoption of new technologies which cause the production frontier to shift outward.

As intimated earlier, this result is strongly consistent with the study of Noor \& Dola (2011) who analysis the role of training on Malaysian livestock farmers' capabilities and performance level in farm. One of the principal ways through which farmers can be taught is by watching television. Television watching creates an awareness of the various platforms through which farmers can solicit for agricultural training. In addition, watching the television one can receive practical lessons on either the use of farm equipment, different methods of farm cultivation as well as fertilizer mixture and application. 
Banking institutions such as agricultural credit unions by their mode of functioning, cannot provide finances to individual farmers or groups of farmers without prior collateral security and guaranty. The farmers on their part will not want to take money that will not yield benefits because the payback can be very traumatizing. Consequently, they will preferably solicit farm training that will permit them to acquire the best performance. Finally, non-poor households are households that will sacrificially spend on training because of their conscious of acquiring knowledge in other to produce substantially.

\section{Food Crop Production}

Table 3 shows statistic tests of influencing the observed variables on the agricultural training. The diagnostic tests indicate that the inputs into agricultural production function are endogenous since the Durbin-Wu-Hausman Chi-square Statistic is 19.328 for a $p$-value of 0.0003 . It also indicates that the OLS estimates are not reliable for inference (column 3 of Table 3). The chi-square statistics is sufficiently high, revealing that the instruments are strongly identified, while the F-statistics on excluded instruments for the input equations are low. It suggests that though the instruments are weak but relevant.

The set of instruments used in the work is said to be valid both for the input equations and for the control function equation. The first-stage $\mathrm{F}$ statistic on excluded instruments varies from about 9.29 to 13.49 ( $p$-value $=0.0000)$, while the Sargan statistic $(0.518, P$-value $=0.4716)$. It proves that the instruments are valid and relevant. However, looking at the Cragg-Donald F-statistic, it realized that though the instruments are relevant, they are marginally weak (3.568[19.93]). Since there are an endogenous regressor and two instruments, it is necessary to check whether over-identification restrictions hold.

The diagnostic test of 2SLS, CF without interaction and with interaction results revealed that household agricultural training strongly correlates with food crop production by 2.7 percent and 2.9 percent respectively. Focusing on the magnitude of the results especially the control variables such as the residual and the interaction term, we observed that the control function results with interaction have a stronger magnitude as compared to the 2SLS and CF without interaction results.

Considering the result of the control function with interaction, we observed for 2.9 percentage points agricultural training is affecting FCP in Cameroon. Training creates awareness, expertise, introduces new techniques of production, effective use of inputs, better management of cropping system and marketing strategy. In fact as noted in the literature section, (Noor \& Dola, 2011) summarized six major benefits as the impact of training on farmers: (a) increased in work quality, (b) increased in farm products, (c) cost savings, (d) time savings, (e) increased in income and (f) increase in networking. This result is consistent with that of Tambi and Nganje (2017), using primary data from Fako division they observed that farmers' agricultural training is strongly correlating with agricultural production.

Other variables contributing to increasing agricultural production are number of agricultural workers in households, log of cost of seeds, log of farm size, primary, secondary, higher education, banking financial institution, farming experience and urban residence (Table 3 ). Ceteris paribus, the greater the number of people in agricultural production given the appropriate production conditions, the greater agricultural performance. The more the people, the more the competition to produce the highest, land is not wasted, the strife to do more is high, training is also requested. All these factors help to increase food crop production. It should be noted that the rate of competition among women in food crop production is greater than that of their male counterpart. In the same way, the lower the cost of input the more seeds will be planted and hence the greater the production capacity of the farm considering that the seeds are planted in the right conditions.

Farm size is another major contributor to agricultural production. Large farm size simply means more space for cultivation, employment of more persons, sowing of more seeds, quest to satisfy many more mouths. This is a logical way of improving agricultural production. Education being primary, secondary and higher has a higher probability of increasing production. In this perspective, Appleton \& Balihuta (1996) confirmed 
that household primary schooling has impacted crop production compared to the developing country average. Mirotchie (1994) confirmed that household primary schooling has impacted crop production compared to the developing country average. Lastly, Weir (1999) examines the effects of schooling upon farmer productivity and efficiency, in which revealed substantial internal private benefits of schooling for farmer productivity. These benefits are in terms of efficiency gains and identified a threshold effect in which at least four years of primary schooling are required to have a significant effect upon farm productivity.

Banking financial institutions supply credits to farmers to encourage them to: cultivate more land, buy more agricultural input such as seeds, fertilizers, modern plowing machines, reduced manual work by hiring workers hence increasing agricultural production. In addition, farming experience simply means the acquisition of greater skills in farming, mastery of seasonal behavior of crops hence increase in agricultural production. Finally, an urban residence can help promote more training, especially new techniques of production; this can easily increase Food crop production in Cameroon.

\section{Type of Agricultural Training}

The situation of food crop production with respect to the type of agricultural training effect is presented in Table 4. Three types of agricultural training being a professional, workshop or on the farm training, significantly affects agricultural production at one percent level.

Table 4. Relationship Farm Household and Type of Agricultural Training

\begin{tabular}{|c|c|c|c|}
\hline Variables & Professional Training & $\begin{array}{l}\text { Workshop } \\
\text { Training }\end{array}$ & On the Farm Training \\
\hline Farmer Use Modern Farm Technology & $-0.100 * * *$ & $-0.310 * * *$ & $-0.104 * * *$ \\
\hline Number of Agricultural workers in $\mathrm{HH}$ & $0.042 *$ & $0.024 * * *$ & $0.104 * *$ \\
\hline HH Male Sex & $-0.143 * * *$ & $-0.154 * * *$ & $-0.013 * * *$ \\
\hline Log of cost of seeds & $0.901 * * *$ & $0.059 * * *$ & $0.059 * * *$ \\
\hline Log of cost of fertilizer & $-0.021 * * *$ & $-0.092 * * *$ & $-0.022 * * *$ \\
\hline HH Size & -0.005 & $-0.904^{*}$ & $-0.201 * * *$ \\
\hline Primary Education & 0.100 & $0.140 *$ & $0.194 * * *$ \\
\hline Secondary Education & $0.225 * * *$ & $0.202 * * *$ & $0.501 * * *$ \\
\hline Higher Education & $0.608 * * *$ & $0.768 * * *$ & $0.668 * * *$ \\
\hline Farming Experience & $0.104 * * *$ & $0.004 * * *$ & $0.204 * * *$ \\
\hline Predicted Residual & $-0.006 * *$ & $-0.002 * * *$ & $-0.001 * *$ \\
\hline Predicted interaction term & $-0.000 * * *$ & $-0.000 * * *$ & $-0.023 * * *$ \\
\hline Constant & $0.363 * *$ & 0.333 & 0.362 \\
\hline R2 square & 0.7158 & 0.5958 & 0.5158 \\
\hline F-Stat [df; p-val] & $\begin{array}{c}78.68[18,11,301 ; \\
0.0000]\end{array}$ & $\begin{array}{c}83.68[18,11,301 ; \\
0.0000]\end{array}$ & $\begin{array}{c}83.68[18,11,301 ; \\
0.0000]\end{array}$ \\
\hline
\end{tabular}

Source: The 2007 Cameroon Consumption Survey. $\quad$ Notes: ***, ** and * indicate 1\%, 5\% and $10 \%$ levels of significance respectively. The absolute value of robust t-statistics in parentheses are beneath estimates

Professional training is simply the art of receiving specialized training or skills in agriculture, this can possibly be obtained from professional and vocational schools, faculty or research centers and specialized institutions in agriculture (e.g. Faculty of Agronomy and Agricultural Science, IRAD, IITA, CRESA). This result shows that any farmer that has acquired professional training such as agronomist, plant and animal specialist gave appropriate agricultural conditions has a higher probability of producing more in fact to about 2.6 percentage (Table 4) higher as compared to their counterparts who do not have professional training.

Agricultural workshop training is simply a brief intensive course on agricultural education for a small group; emphasize on their interaction to do 
practical problem-solving. It can equally be considered as an academic conference; usually organized by NGOs, Civil Society Organizations, State Agencies such as the Ministry of Agriculture and Rural Development. This result clearly shows that farmers who received agricultural workshop training have probability points of about 0.3 percent of increasing agricultural production as compare to farmers who have not had any workshop training.

The farm training is simply the art of training/teaching farmers on their farm different methods and techniques of agricultural production. By our result, farmers that received on the farm training in agriculture have a probability of about 2.8 percent producing higher than those that do not.

Comparing the result of the three types of training, we observed that the magnitude of on the farm agricultural training is higher than others meaning that the farm training is better in increasing agricultural production as compared to professional and workshop agricultural training.

\section{CONCLUSION AND SUGGESTION}

Agricultural training followed by farm household is strongly and positively correlating with use of modern technology, male household head, cost of fertilizer, household size, higher education, acquisition of television, banking financial support to farmers and non-poor households. Furthermore, agricultural training contributed a 2.9 percentage effect on food crop production. The training creates awareness, expertise, introduces new techniques of production, effective use of inputs, better management of cropping system and marketing strategy.

Farmers who involved in the professional, workshop and on-farm training has a probability points of about 2.6, 0.3 and 2.8 percent of increasing agricultural production as compared to farmers who have not had any training, respectively. The farm training is simply the art of training/teaching farmers on their farm different methods and techniques of agricultural production. Farm training becomes a high priority for increasing agricultural production.
In terms of policy, there are considerable opportunities to take advantage of agricultural training in terms of increase in food crop production. The decision makers, civil society organizations and stakeholders operating in agriculture should multiply agricultural training in both formal and informal training through the creation of agricultural schools, workshop and on the field training.

\section{REFERENCES}

Appleton, S., \& Balihuta, A. (1996). Education and agricultural productivity: Evidence from Uganda. Journal of International Development, 8(3), 415-444. https://doi.org/10.1002/(SICI)10991328(199605)8:3<415::AID-JID396>3.0.CO;2$\underline{9}$

Ashby, J., Hartl, M., Lambrou, Y., Larson, G., Lubbock, A., Pehu, E., \& Ragasa, C. (2008). Investing in Women as Drivers of Agricultural Growth. Washington, DC. Retrieved from http://siteresources.worldbank.org/INTARD/Res ources/webexecutivesummaryARD GiA InvstIn Women $8 \mathrm{Pg}$ web.pdf

Card, D. (2001). Estimating the return to schooling: Progress on some persistent econometric problems. Econometrica, 69(5), 1127-1160. https://doi.org/10.1111/1468-0262.00237

Cotlear, D. (1990). The effects of education on farm productivity. In K. Griffin \& J. Knight (Eds.), Human development and the international development strategy for the 1990s. London: Macmillan. Retrieved from https://www.palgrave.com/br/book/978033353 $\underline{5127}$

Croppenstedt, A., \& Demeke, M. (1997). An empirical study of cereal crop production and technical efficiency of private farmers in Ethiopia: A mixed fixed-random coefficients approach. Applied Economics, 29(9), 12171226. https://doi.org/10.1080/00036849700000012

Epule, T. E., \& Bryant, C. R. (2015). Maize production responsiveness to land use change and climate trends in Cameroon. Sustainability (Switzerland), 7, 384-397. https://doi.org/10.3390/su7010384

Gronau, R. (1977). Leisure, Home Production, and Work--the Theory of the Allocation of Time Revisited. Journal of Political Economy, 85(6), 1099-1123. https://doi.org/10.1086/260629 
Heyneman, S. (1983). Improving the quality of education in developing countries,. Finance and Development, 20(1), 18-21.

Hussain, S., \& Byerlee, D. (1994). Education and farm productivity in post-'green revolution' agriculture in Asia. In G. Peters \& D. D. Hedley (Eds.), The Twenty-Second International Conference of Agricultural Economists, AGRICULTURAL COMPETITIVENESS: MARKET FORCES AND POLICY CHOICE, 22-29 August 1994 (pp. 554-569). Harare, Zimbabwe: International Association of Agricultural Economists, Queen Elizabeth House, University of Oxford.

Lovell, C. A. K. (1993). Production Frontiers and productive efficiency. In H. Fried \& S. Schmidt (Eds.), The measurement of productive efficiency (pp. 3-67). Oxford U.K. https://doi.org/10.1192/bjp.181.43.s91

Mirotchie, M. (1994). Technical efficiency of Ethiopian agriculture. In B. Abegaz (Ed.), Essays on Ethiopian economic development. Avebury. Retrieved from https://books.google.co.id/books?id=dfvsAAAA MAA]

Murshed-E-Jahan, K., \& Pemsl, D. E. (2011). The impact of integrated aquaculture-agriculture on small-scale farm sustainability and farmers' livelihoods: Experience from Bangladesh. Agricultural Systems, 104(5), 392-402. https://doi.org/10.1016/j.agsy.2011.01.003

Närman, A. (1994). Education, training and agricultural development in Zimbabwe. Paris. Retrieved from http://unesdoc.unesco.org/images/0009/00092 1/092104eo.pdf

Noah, H. J. (1988). Education for Development: An Analysis of Investment Choices. In: George Psacharopoulos, Maureen Woodhall. Economic Development and Cultural Change, 36(2), 415419. https://doi.orq/10.1086/451662
Noor, K. B. M., \& Dola, K. (2011). Investigating Training Impact on Farmers' Perception and Performance. International Journal of Humanities and Social Science, 1(6), 145-152. Retrieved from http://www.ijhssnet.com/view.php?u=http://w ww.ijhssnet.com/journals/Vol. 1 No. 6; June 2011/16.pdf

Rosenzweig, M. R. (1995). Why are there returns to schooling? American Economic Review, 85(2), 153-158. https://doi.org/10.2307/2117910

Sligo, F. X., \& Massey, C. (2007). Risk, trust and knowledge networks in farmers' learning. Journal of Rural Studies, 23(2), 170-182. https://doi.org/10.1016/j.jrurstud.2006.06.001

Tanjong, E. (2008). Higher education institutions in Cameroon and their role in sustainable community development. In W. Baiyee (Ed.), International Symposium on The Role of African Higher Education and Sustainable Community Development: The Case for African University, Tali, December 28-30, 2008. Cameroon: African University, Tali. Retrieved from http://www.africanu.org/Documents/2008 Symposium Report.pdf

Tripp, R., Wijeratne, M., \& Piyadasa, V. H. (2005). What should we expect from farmer field schools? A Sri Lanka case study. World Development, 33(10), 1705-1720. https://doi.org/10.1016/j.worlddev.2005.04.012

Weir, S. (1999). The Effects of Education on Farmer Productivity in Rural Ethiopia. Oxford. Retrieved from https://www.csae.ox.ac.uk/materials/papers/99 07text.PDF

Wooldridge, J. M. (2002). Econometric Analysis of Cross Section and Panel Data. MIT Press. Retrieved from https://books.google.co.id/books?id=cdBPOJUP $\underline{4 \mathrm{VsC}}$ 